\title{
Autonomous firing of low-threshold spike interneurons in the striatum
}

\author{
Joseph A Beatty ${ }^{*}$, Charles J Wilson \\ From Nineteenth Annual Computational Neuroscience Meeting: CNS*2010 \\ San Antonio, TX, USA. 24-30 July 2010
}

Specific striatal neuronal subtypes are classified as either phasically or tonically active. Of the four major neuronal subtypes of the striatum, the firing patterns of three have been studied in detail. Spiny projection neurons and fast-spiking interneurons fire phasically in response to synaptic input and are silent when input is absent. Cholinergic (ACh) interneurons are tonically active even in the absence of synaptic input. These ACh interneurons were the only known tonically active neurons in the striatum until recently. We have found that the lowthreshold spike (LTS) interneurons also belong to this classification of striatal tonically active neurons, presenting a new aspect to the striatal oscillatory network.

Striatal LTS interneurons are GABAergic interneurons that also contain neuronal nitric oxide synthase (nNOS), neuropeptide Y (NPY), and somatostatin. We used transgenic mice expressing green fluorescent protein (GFP) under control of the nNOS or NPY promoters to help identify LTS interneurons. GFP positive neurons were examined using whole-cell and cell-attached recording techniques to investigate firing patterns and possible mechanisms of such activity. GFP positive neurons displayed the morphological properties characteristic of LTS interneurons, and fired strong rebound bursts at the offset of hyperpolarizing current pulses. LTS interneurons were spontaneously active and this activity persisted in the presence of synaptic blockers. When compared with ACh interneurons, LTS interneurons fired at higher rates and with less regularity. Similar to ACh interneurons, LTS interneurons were capable of firing in a variety of firing patterns, including regular single spiking, irregular single spiking, and bursting combined with periods of regular and irregular single spiking. LTS interneurons were observed spontaneously shifting between these

\footnotetext{
* Correspondence: joseph.beatty@utsa.edu

Department of Biology, University of Texas at San Antonio, San Antonio, TX 78249, USA
}

firing patterns. Whole-cell voltage clamp recordings revealed a tetrodotoxin-sensitive region of negative slope conductance in the subthreshold range consistent with a persistent sodium current. An absence of a zero current crossing in the I-V curve combined with a linear F-I curve suggest these interneurons possess a Hodgkin's class 1 oscillation mechanism.

Tonically active neurons in the striatum have been shown to become strongly synchronized with the beta oscillation seen in Parkinson's disease. These strongly synchronized neurons may include LTS interneurons. In addition, both ACh and LTS interneurons are capable of endogenous oscillations in the beta frequency range. Our findings place LTS interneurons in the subtype of tonically active neurons in the striatum and in turn change our understanding of how synchronization may occur in the striatum.

Published: 20 July 2010

doi:10.1186/1471-2202-11-S1-P150

Cite this article as: Beatty and Wilson: Autonomous firing of lowthreshold spike interneurons in the striatum. BMC Neuroscience 2010 11(Suppl 1):P150.

Submit your next manuscript to BioMed Central and take full advantage of:

- Convenient online submission

- Thorough peer review

- No space constraints or color figure charges

- Immediate publication on acceptance

- Inclusion in PubMed, CAS, Scopus and Google Scholar

- Research which is freely available for redistribution

Submit your manuscript at www.biomedcentral.com/submit
C BioMed Central 